\title{
Developing Instrument to Measure Student's Capability for Future Work in Industry 4.0 at Vocational Education Culinary Program
}

\author{
https://doi.org/10.3991/ijim.v14i12.15589 \\ Desy Putriana Dewi ${ }^{(凶)}$, Soenar Soekopitojo, Aisyah Larasati \\ Universitas Negeri Malang, Malang, Indonesia \\ desyputrianadewi3@gmail.com \\ Muhammad Farid Kurniawan \\ Universitas Gajahmada, Yogyakarta, Indonesia \\ Era Ria Sofia Hartanti \\ Universitas Merdeka Malang, Malang, Indonesia
}

\begin{abstract}
Contradictions and levels of difficulty in the industrial era 4.0, especially culinary changes occur very quickly which requires humans to have the capability, to become individuals who have the skills to act. This study provides an assessment to measure the capabilities of vocational education students in statistics through instruments that have been designed and examine the competencies and soft skills that affect capabilities for future work in industry 4.0. The instrument was developed through mobile technology using Google Form and this research was conducted using quantitative methods and analyzed by confirmatory factor analysis. A total of 245 respondents from vocational education students in the culinary program were observed using a questionnaire that had been designed. Based on the results of the test analysis of exogenous confirmatory factors and endogenous indicators of capability (literacy, numeracy, ICT, critical and creative thinking, personal and social skills, and ethical understanding) showed significant value, while the reliability relationship with Cronbach alpha showed values $>0.06$ which means significant. Based on the results of the goodness of fit test, this research model is fit which that means the mobile-based instruments that have been developed in this study are feasible to test the capabilities of students in vocational education at culinary programs
\end{abstract}

Keywords-Mobile instrument of capability, student's capability development, capability as human development.

\section{Introduction}

The world is changing, the industrial revolution 4.0 presents a new dynamic characterized by a level of complexity and contradiction in various ways. This change should be responded well, especially student in vocational education and training 
(VET) at culinary program to prepare students to have the capability for future work in industry 4,0 era. Students who have this capability are expected to be responsive, sensitive and flexible to change. Moreover, the population growth described in Indonesian age pyramids, 2010 and 2035 by [1] estimates that in 2035 Indonesia will have a significant growth in productive age between the ages of 15-64 years. Therefore the projected growth of Indonesia's population in this productive age can lead to high competition, according to [2] in some of countries which one is Indonesia, there are only about $4.3 \%$ of the 1000 skilled workers, this is far behind other countries such as Malaysia $32.6 \%$, the Philippines $8.3 \%$, and Singapore $34.7 \%$. This situation clearly proves that the competitiveness of human resources is an absolute necessity to turn challenges into opportunities.

Therefore, capabilities require culinary students to have freedom in determining their respective social roles with the competencies they have to to survive and work in the industry 4.0 era. Vocational education should be able to produce a superior human resources, competitive, skilled, excellence and have the capability to be ready to face the changes that occur continuously. Some experts have explained that capability is being and doing that is influenced by knowledge, competence and skills and can provide basic concepts for the human development that are valuable for the welfare of themselves and others or society and they can be themselves [3]-[6]. In other words, the capability of a student is the result of achievement during the learning process, education in a culinary program should have strategies such as having a reliable curriculum so that the capability of graduates can be achieved optimally.

Indonesian President Joko Widodo has decided that tourism is one of Indonesia's economic strategy pillars. The role of digitalization in industri 4.0 will develop the tourism sector both destinations, restaurants, culinary, hotels and travel agents throughout the world, especially Indonesia, so that government policy needs attention because competition is also increasing, . According to [7] currently low-skilled workers in the tourism sector in Indonesia are relatively high, but low-skilled workers are burdening Indonesia in the tourism industry competition, as well as educational disparities in various provinces. Human development is also needed in this case because it relates to a person's skills for their future lives in terms of income and quality of life [8].

In addition to the development of the culinary and tourism industry in Indonesia in the industrial era 4.0 can be a new challenge, capabilities are needed to answer it all. The purpose of this study is to provide an assessment that measures students' capability in the culinary program in statistics as the human development approach through instruments

\section{Methodology}

The instrument developed by a questionnaire with closed-questions that allows respondents to answer quickly and produce accurate data, and developed using mobile based technology "Google Form", the aim is to facilitate respondents in answering the questionnaire anywhere and anytime and researchers to analyze the results of the questionnaire. In the instrument that has been developed there are 29 questions from 6 
indicators presented including, literacy, numeracy, ICT literacy, critical and creative thinking, personal and social understanding and ethical understanding. In the food literacy indicator there are 7 question items, 5 question items on numeracy indicators, 5 ICT question items, 5 question items on critical and creative thinking indicators, 3 item personal and social capability questions and 4 question items on ethical understanding. To obtain relevant research results, the instrument was validated by two experts at once in terms of the contents of the instrument and the grammar and writing of sentences on instruments. Furthermore, the instrument was distributed to 245 VET students culinary program in Malang, East Java, Indonesia class XII semester 1 with 2013 curriculum (K-13) which is a government-defined curriculum that is applied to the education system in Indonesia and student that had carried out internship program.

The development of Capability instrument indicators is referred to several scientific studies, experts and relevant issues at this time. In these study indicators that have been developed include 1) food literacy; 2) numeracy; 3) ICT literacy; 4) critical and creative thinking; 5) personal and social capability; 6) ethical understanding. All questions from the Capability instrument were developed by 29 questions and used 4 levels of Likert scale with the type of case study statement so that analysis and high order thinking skills are needed.

Table 1. Capability Indicator

\begin{tabular}{|c|c|c|c|c|}
\hline No & $\begin{array}{c}\begin{array}{c}\text { Aspect of the } \\
\text { study }\end{array} \\
\end{array}$ & Indicator & Descriptor & Source \\
\hline 1 & $\begin{array}{l}\text { Proficiency in } \\
\text { reading recipes, } \\
\text { knowledge of basic } \\
\text { food concepts, } \\
\text { interpretation of } \\
\text { food serving }\end{array}$ & Literacy & $\begin{array}{l}\text { 1) Food material knowledge; } \\
\text { 2) Knowledge of the menu } \\
\text { 3) Media for learning and obtaining infor- } \\
\text { mation } \\
\text { 4) Knowledge of food processing techniques; } \\
\text { 5) K3, hygiene and sanitation }\end{array}$ & {$[9]-[14]$} \\
\hline 2 & $\begin{array}{l}\text { Proficiency in food } \\
\text { price conversion } \\
\text { and calculation }\end{array}$ & Numeracy & $\begin{array}{l}\text { 1) Conversion; } \\
\text { 2) Food price calculation }\end{array}$ & {$[9],[12]-[14]$} \\
\hline 3 & $\begin{array}{l}\text { Proficiency in } \\
\text { information literacy } \\
\text { that is relevant to } \\
\text { culinary expertise }\end{array}$ & ICT literacy & $\begin{array}{l}\text { 1) Know the type of information needed } \\
\text { relating to culinary expertise; } \\
\text { 2) Able to process information }\end{array}$ & {$[12],[14],[15]$} \\
\hline 4 & \begin{tabular}{|l|} 
Problem-solving \\
skills, and self- \\
assessment of \\
decision-making \\
skills
\end{tabular} & $\begin{array}{l}\text { Critical and } \\
\text { Creative think- } \\
\text { ing }\end{array}$ & $\begin{array}{l}\text { 1) Identification of problems; } \\
\text { 2) Identify problem-solving strategies; } \\
\text { 3) Make a decision; } \\
\text { 4) Finding problem-solving strategies }\end{array}$ & {$[14],[16]-[20]$} \\
\hline 5 & $\begin{array}{l}\text { Social skills, life } \\
\text { and work abilities } \\
\text { of students }\end{array}$ & $\begin{array}{l}\text { Personal and } \\
\text { social capability }\end{array}$ & $\begin{array}{l}\text { 1) Communication in organizations; } \\
\text { 2) Interacting between individuals }\end{array}$ & $\begin{array}{l}{[4],[12],[14],} \\
{[19]}\end{array}$ \\
\hline 6 & $\begin{array}{l}\text { The capacity to } \\
\text { understand and } \\
\text { apply principles } \\
\text { that are socially and } \\
\text { ethically responsi- } \\
\text { ble when collabo- } \\
\text { rating with others }\end{array}$ & $\begin{array}{l}\text { Ethical under- } \\
\text { standing }\end{array}$ & $\begin{array}{l}\text { 1) Commitment to doing the best work with } \\
\text { full responsibility; } \\
\text { 2) responsible and responsive }\end{array}$ & [4], [14], [19] \\
\hline
\end{tabular}


The instrument that has been distributed then tabulated and analyzed using Confirmatory Factor Analysis (CFA) with AMOS 20 software. The analysis design of the instrument as follows:

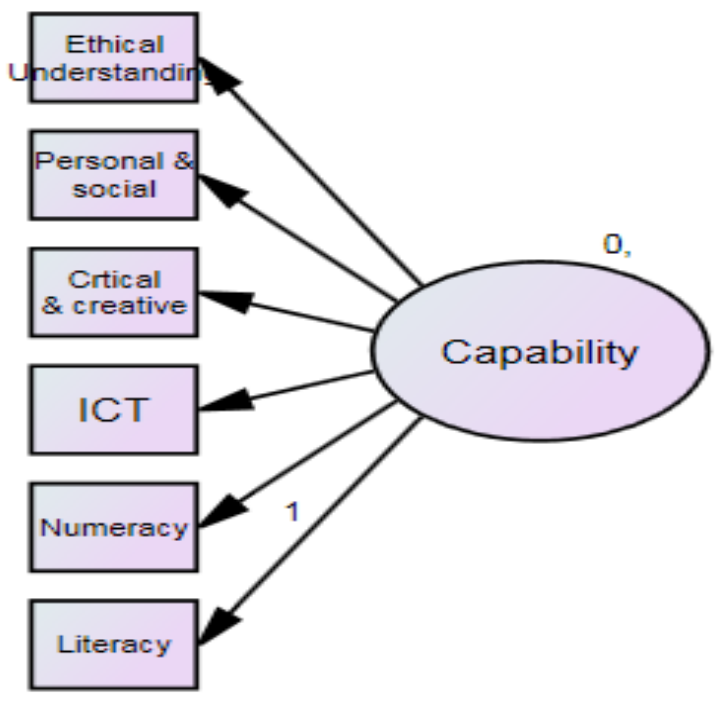

Fig. 1. Analysis Design

\section{$3 \quad$ Result and Discussion}

The results of all respondents' answers were tabulated in Excel and analyzed using confirmatory factor analysis (CFA) with Amos 20. The use of CFA can determine how variables are measured systematically and also logically to represent the constructs involved in a theoretical model. Thus this measurement can provide suggested relationships that show how the measured variables represent latent constructs that are not measured directly through factor loading of the indicator and its interrelationships [21], [22]. Before the analysis is carried out, at least two prerequisite tests of normality analysis and outlier tests must be passed [21]-[23]. In this study, no abnormal data was found and there were no outliers, so it can be ascertained that all data on the $\mathrm{Ca}$ pability instrument is normal and no outliers occur.

\subsection{Confirmatory factor analysis result}

The suitability index value of the CFA model is significant if: $\chi^{2} / \mathrm{DF}<3.790$, CFI $>0.920$, IFI $>0.921$, RMSEA $<0.083$. From the measurement of model fit obtained CMIN / DF> 3, CFI <0.92, IFI <0.921 and RMSEA > 0.083 shows that the constructed model isn't fit or insignificant [23], [24]. The model is modified with a modification index where if the two indicators are correlated there will be a decrease in chi-square by a Modification Index (MI) of that number. However, this modifica- 
tion will inevitably lead to changes in the initial data so it needs to be re-analyzed in normality and outlier. After an analysis of normality and outliers, no abnormal data was found and no outliers occurred. The new model of modification index suggestions is as follows:

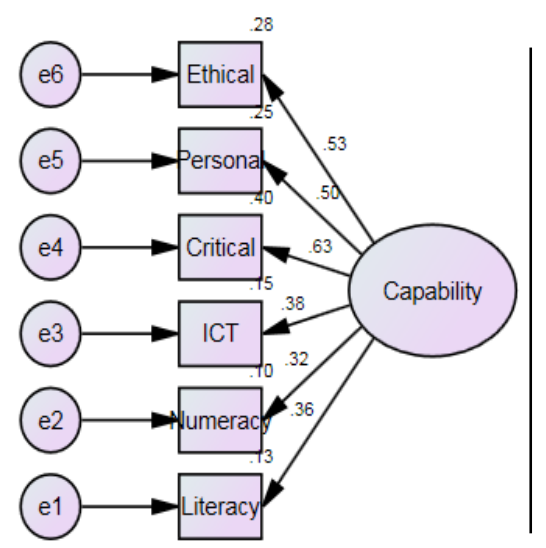

Before Modification Index

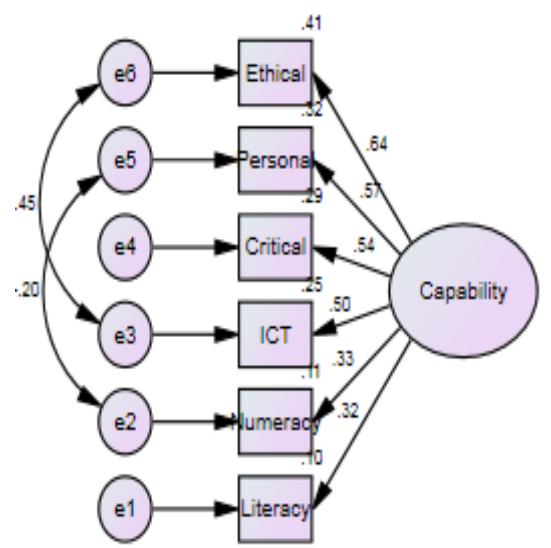

After Modification Index

Fig. 2. New model before and after using modification index suggestions

Modification steps in the model refer to several theories that support the correlation between the modified variables, according to [25] the numeracy variables and personal and social skills have a linear and substantial relationship. By having literacy and numeracy skills, respondents have a better level of emotional stability. The ICT skills variable with ethical understanding according to [26] that rapid changes in ICT technology indicate new ethical challenges, ethics is a reflective correlation and studies of how moral behavior, norms and values can control people's behavior [27]. The existence of correlation and theory above can be used to support the concept of model modification theory

After modifying the index according to suggestions, the validity of the model match index can be obtained. It is known that: $\chi 2 / \mathrm{DF}=1,783$, Probability $=0.083$, $\mathrm{CFI}=0.966$, IFI $=0.969$, RMSEA 0.054 so that this model is fit and significant. In another side, the CMIN / DF ratio is less than 3 and the chi-square value is significant which means the smaller the value the better and shows that the overall suitability of the model is within acceptable limits [22], [28].

Table 2. Model Fit

\begin{tabular}{|c|c|c|c|c|c|c|}
\hline Model & CMIN & Probability & TLI & CFI & IFI & RMSEA \\
\hline Default model & 1.783 & 0.083 & 0.898 & 0.966 & 0.969 & 0.054 \\
\hline
\end{tabular}




\subsection{Validity and reliability analysis}

In the structural equation modelling method, it is necessary to look at the results of the confirmatory factor analysis to determine the convergent validity of the scale used to measure the dimensions which are the conceptual models of research. Confirmatory factor analysis (CFA) was carried out to determine the construct validity of the scale used. When the model is fit, each construct can be evaluated separately by (1) looking at the significance of the loading factor indicator (Standardized regression weight estimate) and (2) evaluating construct reliability and variance extracted AVE) [22]. Based on the results of the CFA analysis on the value of regression weights show CR (critical ratio) $>2$ for all indicators with P-value $<0.05$ which shows that the data in each construct is valid and significant. Whereas for the reliability test using Cronbach Alpha the results obtained $>0.6$ and the results obtained the construct reliability test $>0.7$, and the average variance extracted (AVE) of $>0.5$ so that it can be concluded that the instrument is reliable [23]. Furthermore, for the loading factor criteria value of $>0.5$, but for newly developed instruments a value of 0.4 still needs to be considered. The analysis shows that ICT literacy, Critical and creative thinking indicators, and ethical understanding are significant with values> 0.5 . As for the indicators of literacy, numeracy and personal understanding rounding 0.4 .

\subsection{Direct effect, indirect effect and the total effect}

Based on the results that indicators of food literacy, numeracy skill have a direct effect and a small total effect of 0.4 while the indirect effect is worth 0.00 . This can be interpreted the direct effect between food literacy and capability, numeracy and capability are very small. Although literacy and numeracy it is not too essential to human development [29], according to the WEF report, it is stated that in developing countries including Indonesia, literacy and numeracy skills are very low <25\% [30]. As for the indicators of ICT literacy, critical and creative thinking, personal and social skills and ethical understanding, it states that the direct effect on ICT literacy, personal and social skills and Ethical understanding has 0.5, while for critical and creative thinking the direct effect is 0.7 on Capability.

\subsection{Future work Industry 4.0 at culinary}

Concerning capability with future work in industry 4.0 , driver change technology and as a tool of work in the 21st century, this is essential for VET students, especially in the growing culinary program [31]. According to [32] the Ministry of Industry 80\% of agricultural productivity is poor upstream, infrastructure is still lagging and food safety issues are increasing as well as limitations in the application of technology. Technology also brings major changes to culture and the way people meet their needs such as work and shopping including raw food shopping and ready-to-eat food using the online marketplace. According to [33] the online marketplace makes users feel grateful and satisfied as well as information, social interactions and entertainment such as in Tokepedia and Bukalapak. This phenomenon is happening at this time so that vocational high schools should adapt to develop a reliable curriculum, make classroom learning more comfortable, interesting and flexible by using learning tech- 
nology. According to [34] mobile-based learning can improve students' abilities, the existence of a mobile learning application is a progress and not only text-based, but also video tutorials that are able to show students about the actual process. This is reinforced by research conducted by [35] student productivity will increase with the accuracy of high test scores through the use of modern educational technique in the classroom, and this can save time and less effort such as using LMS (Learning Management System) and using technology in learning activities can provide collaborative learning experiences, stimulate students to learn independently and have involvement [36]

The presence of the industrial revolution 4.0 provides a new industry trend by using technology, analysis of information and connect with various production machines, this will make the industry more efficient, more powerful and able to collaborate [37]. Functional literacy in vocational education culinary programs is a general skill in culinary expertise, this relates to the basic concept of culinary [38] but technology plays an important role in the food and beverage industry because of the demands of consumers to present better food or drinks, in the future, several things will play an important role in the food and beverage industry such as; active packaging, internet of thing such as big data and AI (artificial intelligent), food control and food security [39]. The importance of numerical skills in industry 4.0 is one of the most valued skills in the labor market, besides these skills are related to individual welfare, economic welfare and health, numeracy skills are also recruitment of graduates, poor numeracy skills will limit the appropriateness of graduates working, because this ability is the basis of academic disciplines that must be mastered even in the arts and humaiora sector [40], [41]. Culinary education students, prepared for industry 4.0 workforce, both hotels, restaurants, small and medium businesses, they will be faced with these challenges. Therefore a good preparation for capability, one of which is providing food literacy ad numeracy is very necessary but also there is an urgency about mapping the curriculum, accroding to [42] the curriculum should be reviewed regularly to align with the new competency framework.

Currently the conditions that occur in Indonesia have a low level of ICT, likewise the ethical understanding which is essential in the environment, especially in the workplace, this emphasizes the commitment to do the best work with full responsibility and choose skills and responsiveness. The most essential indicator is critical and creative thinking which is a collaboration of literacy, ICT and communication. So in this case related that literacy, ICT and communication are asset-based-thinking students [29], but the data states that creative and critical thinking in Indonesia is very low <0.20 [29], [30].

The importance of critical and creative thinking for students to promote their work skills other than as a requirement for entering the workplace, this critical and creative thinking is a high-order thinking skill that should be prepared so that students are able to survive in the dynamics of the future. Meanwhile problem solving emphasizes students to have critical thinking skills and have an understanding of experiments and scientific processes, having the ability to solve problems is very important for vocational education students as a provision in workforce in addition to basic knowledge, knowing the making techniques and the skills to make food is needed so they can survive in the industry [38], [43], [44]. 
Personal and social skiils or intrapersonal skills means that a person has the ability to read and manage his emotions, provide motivation, and how during social interactions or in social-interactive contexts he can treat himself and others well, emotional intelligence is also needed to face challenges future work, in addition to that an ethical understanding is needed to form a commitment to do the best and responsible work [4], [44], [45]

The core concept of capability is individual freedom in determining their respective social roles. Capability is a collaboration of one's competencies therefore curriculum is essential in VET schools. An explicit recommendation by [19], [29], [30] that the curriculum and material provided should following the needs and environmental resources, students' cognitive levels, language skills and social-cultural identity and also multidisciplinary. VET schools should develop their multidisciplinary curriculum, for example, the culinary links with tourism, this can be viewed from various aspects that synergize with each other so educators who are prepared but also be capable in this regard because modern travelers today prioritize tourism services that can provide new experiences, emotions, and feelings, including the diversity of nature, culture, hospitality to the community and tourism staff, as well as independent tourism trends supported by technological developments that make it easier for them to plan their vacation [46]

\section{Conclusion}

The instrument model of this study is fit according to the advice of the modification index, the results of the CFA loading factor show several significant and influential indicators, it can be concluded that this instrument is constructed valid. Likewise, the reliability test shows results that are both reliable and AVE. But should to noted that how this capability can grow in VET students in the culinary program for future work in industry 4.0, this instrument is only a measurement tool. Without the relevant knowledge, underlying capabilities aren't optimal, so hopefully, the results of the response this instrument can be the basis for further research and produce data that are useful for future curriculum development.

This study also provides recommendations to the government and VET school developers to provide material reinforcement on food literacy, numeracy, ICT literacy, develop students who have personal and social capability ethical understanding as asset-based thinking for critical and creative thinking through a multidisciplinary curriculum to have capability for future work in industry 4.0.

\section{$5 \quad$ References}

[1] H. Posselt and D. P. Harahap, Indonesian population projection: understanding the causes, consequences and policy options for population and development. Jakarta, Indonesia: United Nations Population Fund Indonesia, 2015.

[2] Asean Productivity Organization, APO Productivity Databook. Tokyo, Japan: Asean Productivity Organization, 2015. 
[3] S. Alkire, "Capability and functionings: definition and justification. Human Development and Capability Association Briefing Note," Hum. Dev. Capab. Assoc., 2005.

[4] P. Anand, G. Hunter, I. Carter, K. Dowding, F. Guala, and M. Van Hees, “The Development of Capability Indicators," J. Hum. Dev. Capab., vol. 10, no. 1, pp. 125-152, Mar. 2009, https://doi.org/10.1080/14649880802675366

[5] E. R. Bach, Critical Capabilities \& Competencies of the Future - Is Change the Only Constant? FranklinCovey, 2017.

[6] I. Robeyns, "The Capability Approach: a theoretical survey," J. Hum. Dev., vol. 6, no. 1, pp. 93-117, Mar. 2005, doi: https://doi.org/10.1080/146498805200034266.

[7] P. Ollivaud and P. Haxton, Making the most of tourism in Indonesia to promote sustainable regional development. OECD, 2019.

[8] M. Appiah, R. Amoasi, and D. Idan Frowne, "Human Development and Its Effects on Economic Growth and Development,” Int. Res. J. Bus. Stud., vol. 12, no. 2, pp. 101-109, Aug. 2019, https://doi.org/10.21632/irjbs.12.2.101-109

[9] A. Brown, Understanding Food Prinples and Preparation. Wadsworth Thomson Learning, 2011.

[10] W. Gisslen, Professional cooking, 7th ed. Hoboken, N.J: John Wiley \& Sons, 2011.

[11] M. H. Jeinie, N. M. Nor, M. S. Md. Sharif, and M. Saad, "Food Hygiene and Safety among Culinary Intern: Questionnaire for FHS Quality," Procedia - Soc. Behav. Sci., vol. 222, pp. 299-305, Jun. 2016, https://doi.org/10.1016/j.sbspro.2016.05.165

[12] N. Nurjanah, "Model Hubungan Literasi Fungsional, Literasi Informasi, Numerasi, Nilai Kerja, Pemecahan Masalah, dan Kreativitas dengan Keahlian Kuliner Siswa SMK Di Malang Raya," Disertasi, Program Studi Pendidikan Kejuruan, Pascasarjana, Universitas Negeri Malang, Malang, Indonesia, 2017. https://doi.org/10.17977/um031v40i22017p147

[13] H. A. Vidgen, "Food literacy: what is it and does it influence what we eat?," Doctoral dissertation, Queensland University of Technology, 2014.

[14] S. Yang, "RETHINKING PEDAGOGIES TO DEVELOP FUTURE READY CAPABILITIES," 2017.

[15] M. Cheng, G.-C. A. Ogbeide, and F. L. Hamouz, "The Development of Culinary Arts and Food Science into a New Academic Discipline-Culinology®," J. Culin. Sci. Technol., vol. 9, no. 1, pp. 17-26, Mar. 2011, https://doi.org/10.1080/15428052.2011.558461.

[16] Cushman \& Wakefield, "THE GLOBAL FOOD \& BEVERAGE MARKET-What's on the Menu?" 2017.

[17] J. D. Floros et al., "Feeding the World Today and Tomorrow: The Importance of Food Science and Technology: An IFT Scientific Review," Compr. Rev. Food Sci. Food Saf., vol. 9, no. 5, pp. 572-599, Aug. 2010, https://doi.org/10.1111/j.1541-4337.2010.00134.x.

[18] S. Ivanovic, L. Perman, and I. Grlj, "IMPACT OF TECHNOLOGICAL DEVELOPMENT ON BUSINESS EFFICIENCY IN THE FOOD AND BEVERAGE DEPARTMENT," UTMS J. Econ., vol. 6, no. 2, pp. 321-330, 2015.

[19] C. L. Scott, “The futures of learning 2: What kind of learning for the 21 st century?," p. 14, 2015. 
[20] I. Siró, E. Kápolna, B. Kápolna, and A. Lugasi, "Functional food. Product development, marketing and consumer acceptance-A review," Appetite, vol. 51, no. 3, pp. 456-467, Nov. 2008, https://doi.org/10.1016/j.appet.2008.05.060.

[21] J. F. Hair, Ed., Multivariate data analysis, 7th ed. Harlow: Pearson, 2014.

[22] J. Sarwono, "Pengertian Dasar Structural Equation Modeling (SEM)," Ilm. Manaj. Bisnis, vol. 10, no. 3, p. 10, 2010.

[23] M. E. Civelek, "Essentials of Structural Equation Modeling," Zea Books, Mar. 2018, doi: 10.13014/K2SJ1HR5.

[24] M. H. Davis, J. A. Hall, and P. S. Mayer, "Developing a new measure of entrepreneurial mindset: Reliability, validity, and implications for practitioners.," Consult. Psychol. J. Pract. Res., vol. 68, no. 1, pp. 21-48, 2016, doi: 10.1037/cpb0000045.

[25] B. Rammstedt, D. Danner, and C. Lechner, "Personality, competencies, and life outcomes: results from the German PIAAC longitudinal study," Large-Scale Assess. Educ., vol. 5, no. 1, p. 2, Dec. 2017, https://doi.org/10.1186/s40536-017-0035-9.

[26] C. V. Thornley, S. Murnane, S. McLoughlin, M. Carcary, E. Doherty, and L. Veling, "The Role of Ethics in Developing Professionalism Within the Global ICT Community." Int. J. Hum. Cap. Inf. Technol. Prof., vol. 9, no. 4, pp. 56-71, Oct. 2018, https://doi.org/10.4018/ ijhcitp.2018100104.

[27] I. Karlsson, "Ethics and Information and Communication Technology," IFAC Proc. Vol., vol. 36, no. 22, pp. 75-80, Sep. 2003, doi: 10.1016/S1474-6670(17)37696-6.

[28] D. Ary, L. C. Jacobs, and A. Razavieh, Introduction to research in education, 8th ed. Belmont, CA: Wadsworth, 2010.

[29] L. Tikly, "Reconceptualizing TVET and development: a human capability and social justice approach," Revisiting Glob. Trends TVET Reflect. Theory Pract., pp. 1-39, 2013.

[30] World Economic Forum, New vision for education: Unlocking the potential of technology. British Columbia Teachers' Federation., 2015.

[31] World Economic Forum, "The future of jobs: Employment, skills and workforce strategy for the fourth industrial revolution.," Geneva., Jan. 2016.

[32] R. B. Mahardika, Mengenal Industri Makanan dan Minuman di Era Industri 4.0, Cetakan ke-1. Forbil Institute, 2018.

[33] H. Humaizi, S. Asmara, R. L. Sis, and M. Yusuf, "The Use of Online Marketplace Website in Indonesia: A Study of Consumers' Motives and Gratification,” Int. J. Interact. Mob. Technol. IJIM, vol. 14, no. 07, p. 133, May 2020, https://doi.org/10.3991 lijim.v14i07.11385.

[34] M. I. Qureshi, N. Khan, S. M. A. Hassan Gillani, and H. Raza, "A Systematic Review of Past Decade of Mobile Learning: What we Learned and Where to Go," Int. J. Interact. Mob. Technol. IJIM, vol. 14, no. 06, p. 67, Apr. 2020, https://doi.org/10.3991 lijim.v14i06.13479.

[35] A. H. Alaidi, O. Yahya, and H. TH. S. Alrikabi, "Using Modern Education Technique in Wasit University," Int. J. Interact. Mob. Technol. IJIM, vol. 14, no. 06, p. 82, Apr. 2020, https://doi.org/10.3991/ijim.v14i06.11539

[36] R. H. Rafiola, P. Setyosari, C. L. Radjah, and M. Ramli, "The Effect of Learning Motivation, Self-Efficacy, and Blended Learning on Students' Achievement in The Industrial 
Revolution 4.0," Int. J. Emerg. Technol. Learn. IJET, vol. 15, no. 08, p. 71, Apr. 2020, https://doi.org/10.3991/ijet.v15i08.12525.

[37] B. Bagheri, S. Yang, H.-A. Kao, and J. Lee, "Cyber-physical Systems Architecture for Self-Aware Machines in Industry 4.0 Environment," IFAC-Pap., vol. 48, no. 3, pp. 16221627, 2015, https://doi.org/10.1016/j.ifacol.2015.06.318.

[38] N. Nurjanah, S. Sonhadji, W. Kamdi, and L. Nurlaela, "Functional Literacy Skills And Problem Solving Skills In Culinary Vocational School," in Proceedings of the 1st International Conference on Social, Applied Science and Technology in Home Economics (ICONHOMECS 2017), Surbaya, Indonesia, 2018, https://doi.org/10.2991/iconhomecs17.2018.2.

[39] A. Luque, M. E. Peralta, A. de las Heras, and A. Córdoba, "State of the Industry 4.0 in the Andalusian food sector," Procedia Manuf., vol. 13, pp. 1199-1205, 2017, https://doi.org/10.1016/j.promfg.2017.09.195.

[40] J. Nicholas, "Numeracy practices and numeracy skills among adults," 2018.

[41] N. Durrani and V. N. Tariq, "The role of numeracy skills in graduate employability," Educ. Train., vol. 54, no. 5, pp. 419-434, Jun. 2012, https://doi.org/10.1108 100400911211244704.

[42] M. Saxena and M. Kasparian, "Establishing a Sustainable Process to Measure Learner Performance,” Int. J. Learn. Anal. Artif. Intell. Educ. IJAI, vol. 2, no. 1, p. 31, Mar. 2020, https://doi.org/10.3991/ijai.v2i1.13083.

[43] H. J. Passow and C. H. Passow, "What Competencies Should Undergraduate Engineering Programs Emphasize? A Systematic Review: Undergraduate Engineering Competencies: A Sytematic Review," J. Eng. Educ., vol. 106, no. 3, pp. 475-526, Jul. 2017, https://doi.org/10.1002/jee.20171.

[44] P. Turiman, J. Omar, A. M. Daud, and K. Osman, "Fostering the 21st Century Skills through Scientific Literacy and Science Process Skills," Procedia - Soc. Behav. Sci., vol. 59, pp. 110-116, Oct. 2012, https://doi.org/10.1016/j.sbspro.2012.09.253.

[45] B. Xing and T. Marwala, "Implications of the Fourth Industrial Age for Higher Education," The_Thinker, vol. 73, p. 6, 2017.

[46] A. Polukhina, A. Tarasova, and A. Arnaberdiyev, "Information Technologies: Leading Innovative Factor for the Development of Independent Tourism," Int. J. Recent Contrib. Eng. Sci. IT IJES, vol. 8, no. 1, p. 81, Mar. 2020, https://doi.org/10.3991/ijes.v8i1.14253.

\section{Authors}

Desy Putriana Dewi is graduate student in Faculty of Engineering at Universitas Negeri Malang, Jl. Surabaya 5 A Malang, Indonesia. His research interest includes: Technopreneurship in culinary, capability for vocational education student, culinary and food safety (email : desyputrianadewi3@gmail.com).

Soenar Soekopitojo is senior lecturer in Faculty of Engineering at Industrial Technology Department, Universitas Negeri Malang, Jl. Surabaya 5 A Malang, Indonesia. (email: soenar.soekopitojo.ft@um.ac.id). 
Aisyah Larasati is senior lecturer in Faculty of Engineering at Technology Industry Department at Universitas Negeri Malang, Jl. Surabaya 5 A Malang, Indonesia. (email: aisyah.larasati.ft@um.ac.id).

Muhamad Farid Kurniawan is graduate student at Tourism Studies Departement, Universitas Gajahmada, Bulaksumur, Kabupaten Sleman, Daerah Istimewa Yogyakarta, Indonesia. (email: kurniawanfarid92@mail.ugm.ac.id).

Era Ria Sofia Hartanti is graduate student in Faculty of Magister Management at Toursim Management Program, Universitas Merdeka Malang, Jl. Terusan Dieng 6264 Klojen, Malang, Indonesia. (email:erarian06@gmail.com)

Article submitted 2020-05-15. Resubmitted 2020-06-24. Final acceptance 2020-06-25. Final version published as submitted by the authors. 